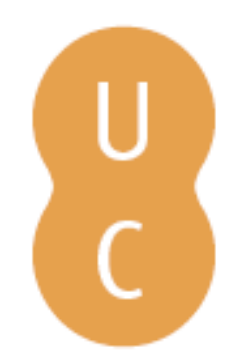

\title{
pommalina
}

\section{The stand flammability classes}

Autor(es): $\quad$ Kwiatkowski, Miroslaw; Szczygiel, Ryszard; Kolakowski, Bartlomiej

Publicado por: Imprensa da Universidade de Coimbra

URL

persistente: URI:http://hdl.handle.net/10316.2/44533

DOI: $\quad$ DOI:https://doi.org/10.14195/978-989-26-16-506_16

Accessed : $\quad$ 26-Apr-2023 11:24:15

A navegação consulta e descarregamento dos títulos inseridos nas Bibliotecas Digitais UC Digitalis, UC Pombalina e UC Impactum, pressupõem a aceitação plena e sem reservas dos Termos e Condições de Uso destas Bibliotecas Digitais, disponíveis em https://digitalis.uc.pt/pt-pt/termos.

Conforme exposto nos referidos Termos e Condições de Uso, o descarregamento de títulos de acesso restrito requer uma licença válida de autorização devendo o utilizador aceder ao(s) documento(s) a partir de um endereço de IP da instituição detentora da supramencionada licença.

Ao utilizador é apenas permitido o descarregamento para uso pessoal, pelo que o emprego do(s) título(s) descarregado(s) para outro fim, designadamente comercial, carece de autorização do respetivo autor ou editor da obra.

Na medida em que todas as obras da UC Digitalis se encontram protegidas pelo Código do Direito de Autor e Direitos Conexos e demais legislação aplicável, toda a cópia, parcial ou total, deste documento, nos casos em que é legalmente admitida, deverá conter ou fazer-se acompanhar por este aviso. 


\section{ADVANCES IN}

\section{FOREST FIRE RESEARCH}

\section{8}

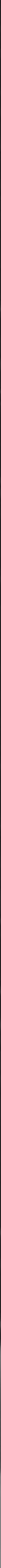




\title{
The stand flammability classes
}

\author{
Miroslaw Kwiatkowski; Ryszard Szczygiel; Bartlomiej Kolakowski* \\ Forest Research Institute. Sękocin Stary, 3, Braci Leśnej Street, 05-090 Raszyn, Poland. \\ \{m.kwiatkowski@ibles.waw.pl,r.szczygiel@ibles.waw.pl,b.kolakowski@ibles.waw.pl*\}
}

\begin{abstract}
The fire risk classification now applied in Poland to forest areas is based on the frequency of fire outbreaks and the stand-related, climatic and anthropogenic conditions. The minimum area for which the forest risk category is determined is the area of a forest district (on average seventeen thousand five hundred ha), which reaches a maximum area of up to thirty-odd thousand hectares. The classification enables the determination of the fire risk for a county, sub-region or province, or the Regional Directorate of State Forests. Thus, this method enables identification of the potential fire risk on the macro scale. However, it is impossible to identify the fire risk on the micro scale.

The classification of stand flammability according to forest habitat types, which has been developed as a result of the implementation of the project and fuel models, shall enable the mapping of forests in terms of their fire characteristics at the sub-compartment level.
\end{abstract}

Keywords: forest fire risk categories, stand flammability classes, forest habitat types, soil cover types

\section{Introduction}

The fire risk classification now applied in Poland to forest areas is based on the frequency of fire outbreaks and the stand-related, climatic and anthropogenic conditions. The minimum area, for which the forest risk category is determined, is the area of a forest district (on average seventeen thousand five hundred ha), which has a maximum area of up to thirty-odd thousand hectares. The classification enables the determination of the fire risk for a county, sub-region or province, or the Regional Directorate of State Forests. Thus, this method enables identification of the potential fire risk on the macro scale. However, it is impossible to identify the fire risk on the micro scale.

The classification of stand flammability according to forest habitat types, which has been developed as a result of the implementation of the project and fuel models, shall enable the mapping of forests in terms of their fire characteristics at the sub-compartment level. This shall meet the requirements of Directive 2007/2/EC of the European Parliament and of the Council of 14 March 2007 establishing an Infrastructure for Spatial Information in the European Community (INSPIRE), which is implemented in Poland by the Ministry of the Environment. One of the expected effects of the implementation of the Directive is the possibility of mapping forest fire risks. At present, forest areas are mapped in terms of fire risk at two levels:

1. The national level, the classification of the Regional Directorates of State Forests (provinces, sub-regions) according to forest fire risk categories,

2. The regional level, the classification of forest districts (counties) according to forest fire risk categories.

The project involved the separation of a third forest fire risk mapping level, the local level of a forest district, considering flammability classes determined by a flammability analysis of forest habitat types and soil cover types. The fire risk mapping method provided for the use of necessary valuation data from the Information System of State Forests (SILP). Since a sub-compartment was a basic mapping unit, this led to very detailed, but too meticulous and fuzzy mapping, which could limit its practical usefulness in certain situations. Therefore, data generalisation rules were developed to enable 
the determination of the flammability class for larger areas, a compartment and a forest district. It was decided that a generalised class should be a weighted mean of the classes of individual subcompartments, with the qualification that where the area of the stands of any class exceeded $50 \%$ of the surface of a given area, it was assigned as a whole to that class.

\section{Methodology}

The stand flammability classification according to forest habitat types was based on an analysis of fire outbreaks in State Forests in the period from 2007 to 2017. In elaborating it, when calculating the flammability index consideration was given to the number of fires and the burnt area relative to the area occupied by particular forest habitat types and soil cover types. This index was the quotient of the proportion of fires or the burnt area and the proportion of a given stand type. In relation to the number of fires, consideration was only given to those sub-compartments where a fire had occurred, whereas in relation to the burnt area the total area affected by a fire was taken into account. These data were referred to current information about the areas of stands growing on particular sites and the soil cover types identified from detailed data on all the sub-compartments found in the Forest Data Bank. The classification of stands in terms of fire risk shall enable assessing it at the sub-compartment level and to create an LMN (Forest Numeric Map) layer with precise fire risk mapping. In elaborating the final classification method, the weights of individual indices were dependent on the correlation strength of the density of fires or the burnt area and the presence of selected stand types.

\section{Results}

\subsection{Classification of stand flammability according to forest habitat type and soil cover type.}

The analysis of the forest fire occurrence, which the classification of the stands is based on, distinctly shows the domination of the tree habitat types, considering both the number of forest fires and the burnt area. Regarding the volume of this publication, authors focused only at the results for lowland habitats covering almost $90 \%$ of Polish forests. These are: fresh coniferous, fresh mixed coniferous and fresh mixed broadleaved forest. The domination of these habitat types is mostly linked to the area covered by them. More accurate information regarding stands flammability is derived from flammability indices - both for number of forest fires and burnt area (table 1). In terms of the number of fires, dry coniferous, moist mixed coniferous, moist coniferous, fresh coniferous, and fresh mixed coniferous forest sites should be considered as the most flammable (with flammability indices higher than 1), whereas in the case of the burnt area these are, respectively, dry coniferous, moist coniferous, bog coniferous, moist mixed coniferous, fresh coniferous, fresh mixed coniferous and fresh mixed broadleaved forest sites. It is noticeable that for the wet sites flammability indices of burnt area is frequently higher than the one for the number of fires.

Table 1 - The occurrence of fires depending on forest habitat types and flammability indices.

\begin{tabular}{|c|c|c|c|c|c|}
\hline \multirow{2}{*}{ Forest habitat type } & \multirow{2}{*}{$\begin{array}{l}\text { Share of total } \\
\text { stand area [\%] }\end{array}$} & \multirow{2}{*}{$\begin{array}{l}\text { Share of number of } \\
\text { forest fires [\%] }\end{array}$} & \multirow{2}{*}{$\begin{array}{c}\text { Share of burnt } \\
\text { area }[\%]\end{array}$} & \multicolumn{2}{|c|}{$\begin{array}{c}\text { Flammability index according } \\
\text { to habitat type }\end{array}$} \\
\hline & & & & $\begin{array}{l}\text { For number of } \\
\text { fires }\left(W_{S L}\right)\end{array}$ & $\begin{array}{l}\text { For burnt } \\
\text { area }\left(W_{S P}\right)\end{array}$ \\
\hline $\begin{array}{c}\mathrm{Bb}-\text { bog coniferous } \\
\text { forest }\end{array}$ & 0.15 & 0.06 & 0.34 & 0.39 & 2.28 \\
\hline $\begin{array}{l}\mathrm{BMb}-\text { bog mixed } \\
\text { coniferous forest }\end{array}$ & 0.63 & 0.39 & 0.51 & 0.62 & 0.80 \\
\hline $\begin{array}{c}\text { BMśw - fresh mixed } \\
\text { coniferous forest }\end{array}$ & 23.66 & 32.99 & 26.31 & 1.39 & 1.11 \\
\hline $\mathrm{BMw}$ & 4.44 & 7.06 & 9.56 & 1.59 & 2.15 \\
\hline $\begin{array}{c}\mathrm{Bs}-d r y \text { coniferous } \\
\text { forest }\end{array}$ & 0.17 & 0.58 & 2.25 & 3.40 & 13.17 \\
\hline
\end{tabular}

Advances in Forest Fire Research 2018 - Page 166 


\begin{tabular}{|c|c|c|c|c|c|}
\hline $\begin{array}{c}\text { Bśw-fresh coniferous } \\
\text { forest }\end{array}$ & 19.72 & 28.90 & 28.22 & 1.47 & 1.43 \\
\hline $\begin{array}{c}\mathrm{Bw}-\text { moist coniferous } \\
\text { forest }\end{array}$ & 0.61 & 0.93 & 4.42 & 1.53 & 7.27 \\
\hline $\mathrm{L} 1$ - riparian forest & 0.47 & 0.31 & 0.38 & 0.65 & 0.80 \\
\hline $\begin{array}{l}\mathrm{LMb}-\text { bog mixed } \\
\text { broadleaved forest }\end{array}$ & 0.73 & 0.15 & 0.14 & 0.20 & 0.20 \\
\hline $\begin{array}{l}\text { LMśw-fresh mixed } \\
\text { broadleaved forest }\end{array}$ & 19.07 & 14.54 & 11.79 & 0.76 & 0.62 \\
\hline $\begin{array}{l}\mathrm{LMw}-\text { moist mixed } \\
\text { broadleaved forest }\end{array}$ & 3.82 & 3.55 & 3.97 & 0.93 & 1.04 \\
\hline $\begin{array}{l}\text { Lśw - fresh broadleaved } \\
\text { forest }\end{array}$ & 9.79 & 3.52 & 3.93 & 0.36 & 0.40 \\
\hline $\begin{array}{c}\mathrm{Lw}-\text { moist broadleaved } \\
\text { forest }\end{array}$ & 1.95 & 0.62 & 0.73 & 0.32 & 0.38 \\
\hline $\mathrm{Ol}$ - alder forest & 179 & 0.41 & 0.55 & 0.23 & 0.30 \\
\hline $\mathrm{OlJ}$ - alder-ash forest & 0.81 & 0.12 & 009 & 0.14 & 0.11 \\
\hline
\end{tabular}

It is clearly visible that estimating the occurrence of the same group of fires in relation to soil cover around $50 \%$ occur in stands with turf (table 2). However, when the share of stands with turf is close to $60 \%$, both for number of fires and burnt area, flammability indices are close to 0.8 . The highest values of flammability index, in both cases, occur for stands with bare ground. Still, considering insignificant (less than 1\%) share of stands with bare ground, it does not influence the characteristic of fires occurrence.

Table 2 - The occurrence of fires depending on the soil cover types and forest flammability indices.

\begin{tabular}{|c|c|c|c|c|c|}
\hline \multirow{2}{*}{ Soil cover type } & \multirow{2}{*}{$\begin{array}{l}\text { Share of total } \\
\text { stand area }[\%]\end{array}$} & \multirow{2}{*}{$\begin{array}{l}\text { Share of number of } \\
\text { forest fires [\%] }\end{array}$} & \multirow{2}{*}{$\begin{array}{c}\text { Share of burnt } \\
\text { area }[\%]\end{array}$} & \multicolumn{2}{|c|}{$\begin{array}{l}\text { Flammability index } \\
\text { according to habitat type }\end{array}$} \\
\hline & & & & $\begin{array}{l}\text { For number of } \\
\text { fires }\left(W_{P L}\right)\end{array}$ & $\begin{array}{c}\text { For burnt } \\
\text { area }\left(W_{P P}\right)\end{array}$ \\
\hline MSZ-moss & 15.43 & 18.78 & 13.38 & 1.22 & 0.87 \\
\hline MSZC - moss/bilberry & 11.53 & 5.33 & 5.16 & 0.46 & 0.45 \\
\hline NAGA - bare & 0.42 & 0.65 & 1.03 & 1.53 & 2.44 \\
\hline SZAD - turf (dense) & 16.34 & 1289 & 19.29 & 0.79 & 1.18 \\
\hline $\mathrm{SZCH}$ - weed (dense) & 8.65 & 5.12 & 6.93 & 0.59 & 0.80 \\
\hline ŚCIO - litter & 4.01 & 4.47 & 4.36 & 1.11 & 1.09 \\
\hline ZAD - turf & 57.09 & 48.18 & 45.81 & 0.84 & 0.80 \\
\hline ZIEL-herbaceous & 13.48 & 4.60 & 4.04 & 0.34 & 0.30 \\
\hline
\end{tabular}

Another stage involved an attempt to assess the importance of particular indices for establishing the method for classifying the stand flammability where the flammability index determined for the number of fires was higher than 1 . In relation to the number of fires, the investigation concerned the correlation of the density of fires (the number of fires in 10,000 ha of a forest area) in forest districts with their proportion of stands growing on the sites BMśw, BMw, Bs, Bśw, Bw and also with their proportion of stands growing on the sites with moss, bare ground and litter.

In relation to the burnt area, the investigation concerned the correlation of its density (the burnt area in 10,000 ha of a forest area) with their proportion of stands growing on the sites Bb, BMśw, BMw, Bs, Bśw, Bw, LMw and also with their proportion of stands growing on the sites with bare ground, dense turf and litter.

Figure 1 illustrates the relation between share of forest habitat types and density of fires. 


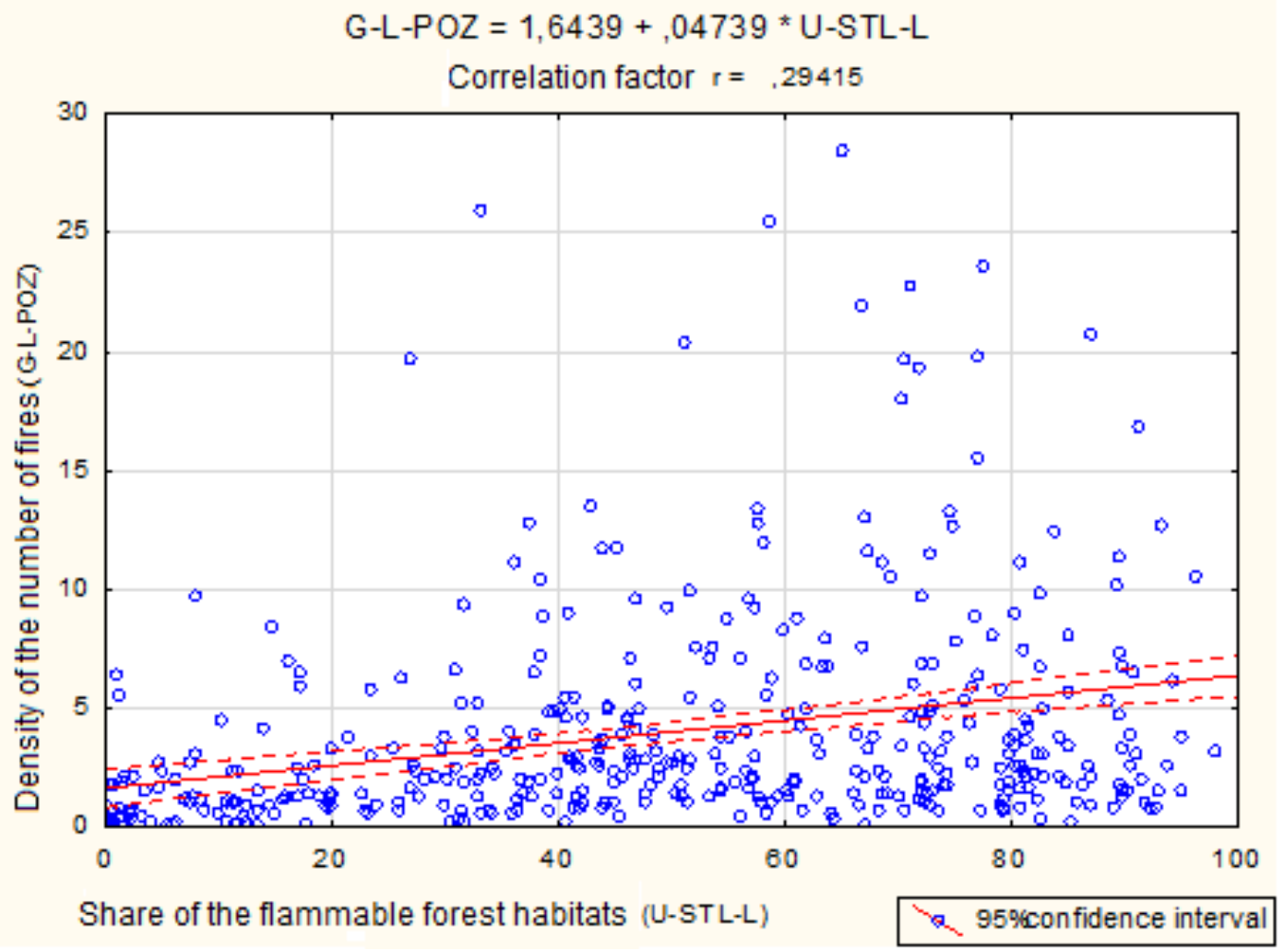

Figure 1 - The correlation between density of fires (GL - POZ) and share of forest habitat types (U-STL-L)

In all the cases, this correlation was poor, with the highest correlation coefficient found for the density of the number of fires depending on the proportion of forest habitat types $(r=0.2941)$, followed by the density of the burnt area depending on the proportion of forest habitat types $(r=0.2158)$.

In relation to the proportion of soil cover types, this was, respectively, $r=0.1710$ for the burnt area and $\mathrm{r}=0.1660$ for the number of fires.

Taking the above into account, the formula for the cumulative flammability index was derived:

where:

$$
W_{S}=0.8 \cdot W_{S L}+0.4 \cdot W_{S P}+i f\left(W_{P P}>W_{P L}\right) 0.3
$$

$W_{S L}$ - the flammability index of forest habitat types for the number of fires,

$W_{S P}$ - the flammability index of forest habitat types for the burnt area,

$W_{P L}$ - the flammability index of forest soil cover types for the number of fires,

$W_{P P}$ - the flammability index of forest soil cover types for the burnt area.

On this basis, it is possible to determine the stand risk class, in accordance with Table 3.

Table 3 - The intervals of the cumulative flammability index for the stand flammability classes.

\begin{tabular}{|c|c|}
\hline Value of cumulative flammability index $W_{S}$ & Flammability classes \\
\hline$\geq 1,7$ & A (high) \\
\hline $0,7 \div 1,7$ & B (medium) \\
\hline$\leq 0,7$ & C (low) \\
\hline
\end{tabular}

According to the assumption above, all the stands (considering forest habitat type and soil cover) should be included in one of the below flammability classes (Table 4). 
Table 4 - The stand flammability classes in relation to the forest habitat type and soil cover

\begin{tabular}{|c|c|c|c|c|c|c|c|c|}
\hline \multirow{2}{*}{$\begin{array}{c}\text { Forest habitat } \\
\text { type }\end{array}$} & \multicolumn{8}{|c|}{ Soil cover } \\
\hline & $M S Z$ & $M S Z C$ & $N A G A$ & $S Z A D$ & $\mathrm{SZCH}$ & SCIO & $Z A D$ & ZIEL \\
\hline$B b$ & $B$ & $B$ & $B$ & $B$ & $B$ & $B$ & $B$ & $B$ \\
\hline$B M b$ & $B$ & $B$ & $B$ & $B$ & $B$ & $B$ & $B$ & $B$ \\
\hline$B M s^{\prime} w$ & $B$ & $B$ & $\bar{A}$ & $\bar{A}$ & $\bar{A}$ & $B$ & $B$ & $B$ \\
\hline$B M w$ & $A$ & $A$ & $A$ & $A$ & $A$ & $A$ & $A$ & $A$ \\
\hline$B s$ & $A$ & $A$ & $A$ & $A$ & $A$ & $A$ & $A$ & $A$ \\
\hline$B s ́ w$ & $\bar{A}$ & $A$ & $A$ & $\bar{A}$ & $A$ & $A$ & $A$ & $A$ \\
\hline$B w$ & $A$ & $A$ & $A$ & $A$ & $\bar{A}$ & $A$ & $A$ & $A$ \\
\hline$L t$ & $B$ & $B$ & $B$ & $B$ & $B$ & $B$ & $B$ & $B$ \\
\hline$L t G$ & $C$ & $C$ & $C$ & $C$ & $C$ & $C$ & $C$ & $C$ \\
\hline$L M b$ & $C$ & $C$ & $C$ & $C$ & $C$ & $C$ & $C$ & $C$ \\
\hline 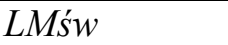 & $B$ & $B$ & $B$ & $B$ & $B$ & $B$ & $B$ & $B$ \\
\hline$L M w$ & $B$ & $B$ & $B$ & $B$ & $B$ & $B$ & $B$ & $B$ \\
\hline$L s ́ w$ & $C$ & $C$ & $B$ & $B$ & $B$ & $C$ & $C$ & $C$ \\
\hline$L w$ & $C$ & $C$ & $B$ & $B$ & $B$ & $C$ & $C$ & $C$ \\
\hline $\mathrm{Ol}$ & $C$ & $C$ & $C$ & $C$ & $C$ & $C$ & $C$ & $C$ \\
\hline OlJ & $C$ & $C$ & $C$ & $C$ & $C$ & $C$ & $C$ & $C$ \\
\hline
\end{tabular}

According to the elaborated method flammability classes were established for all sub-compartments in Poland based on the data derived from Forest Data Bank, as on 31.12.2016. The largest area is covered by the stands with "B" class, which constitute $51.5 \%$ of the total forest area, followed by "A" class stands covering $27.9 \%$ of forest land. The less numerous are the stands marked as "C" class, covering $20.6 \%$ of forest land in Poland. This data is close to the share of the forest land according to the forest fire risk categories, which constitute (as on 31.12.2016) 34.7\% for I category (highest risk), 46.79\% II category (medium risk), and $18.4 \%$ for III category (low risk).

\subsection{Mapping of forest fire risk according to flammability classes and fuel type.}

The way of mapping forest risk is presented using part of the Regional Directorate in Katowice. The forest area of the presented part (figure 2) is more than 65000 ha and includes forest districts marked as I and II forest fire risk category. Figure 3 illustrates the classification of the stands using flammability classes. The greatest share constitutes "B" class with $49.5 \%$ of forest land, followed by "A" class with $34.3 \%$ of forest land and " $\mathrm{C}$ " with $16.2 \%$ of forest land. Figure 4 illustrates flammability classes generalised to the level of compartment. In the last case the share of the "B" class is bigger than above $(50.8 \%)$, while the remaining classes constitute less than above ("A" $-34.1 \%$ and "C" $15.1 \%$ ). The third, the most general level of spatial accuracy, is the level of forest range and it is illustrated on figure 5. In this case "B" share equals to $53.1 \%$, followed by "A" class with $32.5 \%$ of forest land and "C" class with only $14.4 \%$. 


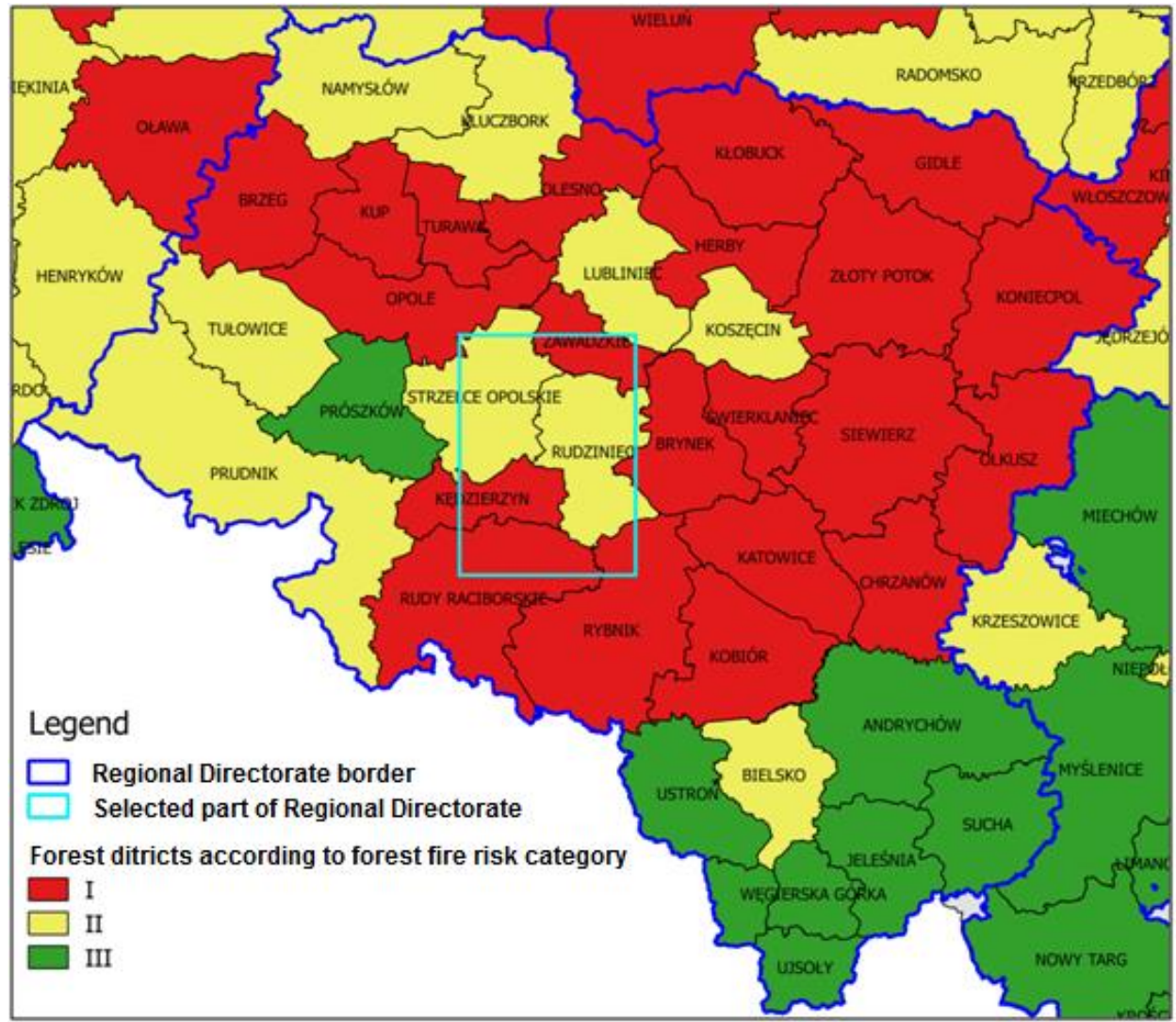

Figure 3 - The forest districts of Regional Directorate in Katowice according to the forest fire risk category with the selected part for conducting forest fire danger mapping.

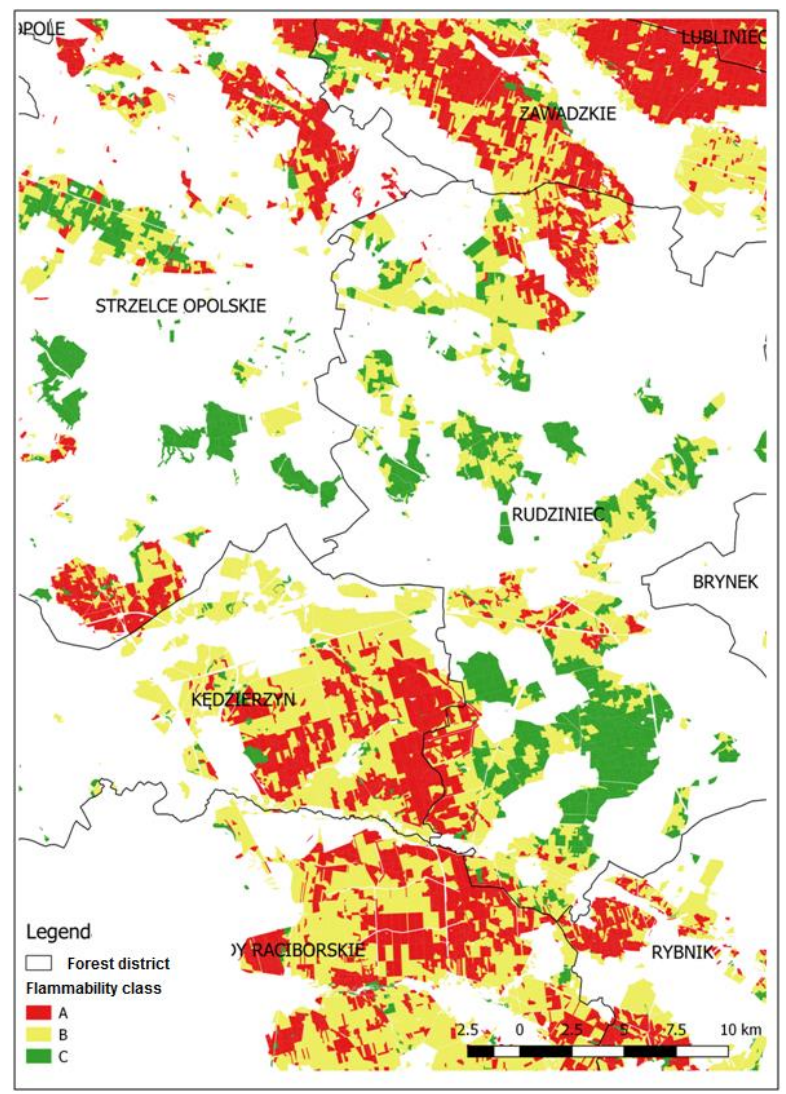

Figure 3 - Forest fire danger map for Regional Directorate in Katowice - flammability classes at the sub-compartment level. 


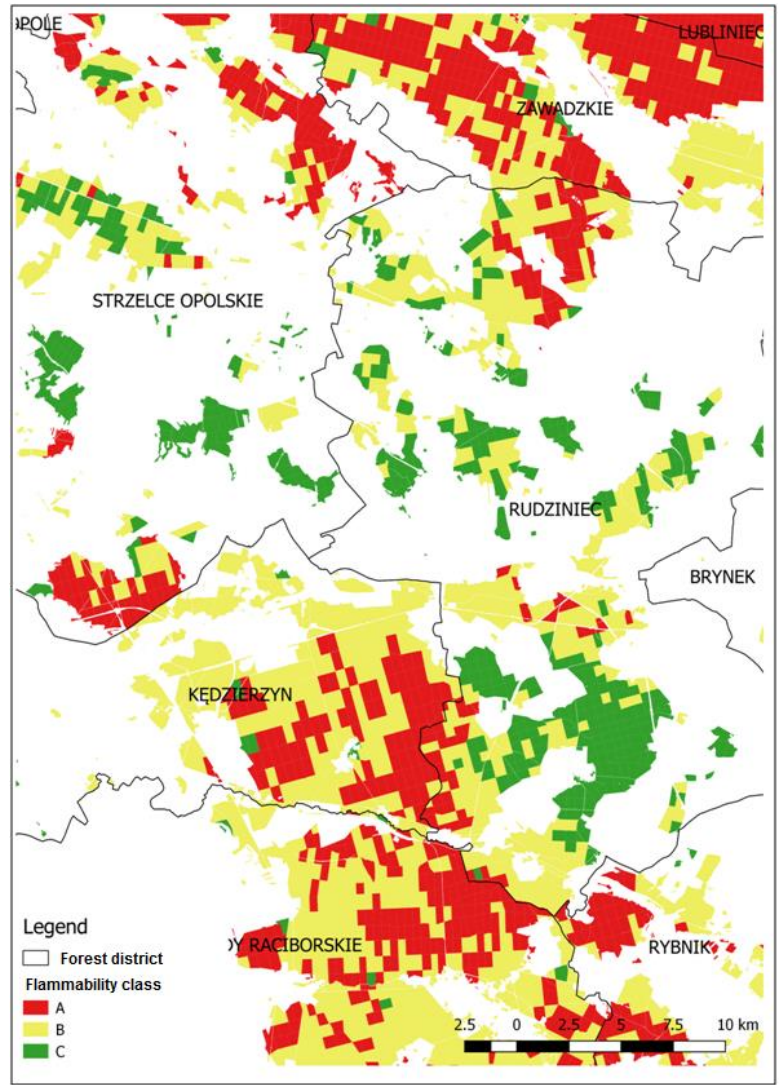

Figure 4 - Forest fire danger map for Regional Directorate in Katowice - flammability classes at the compartment level.

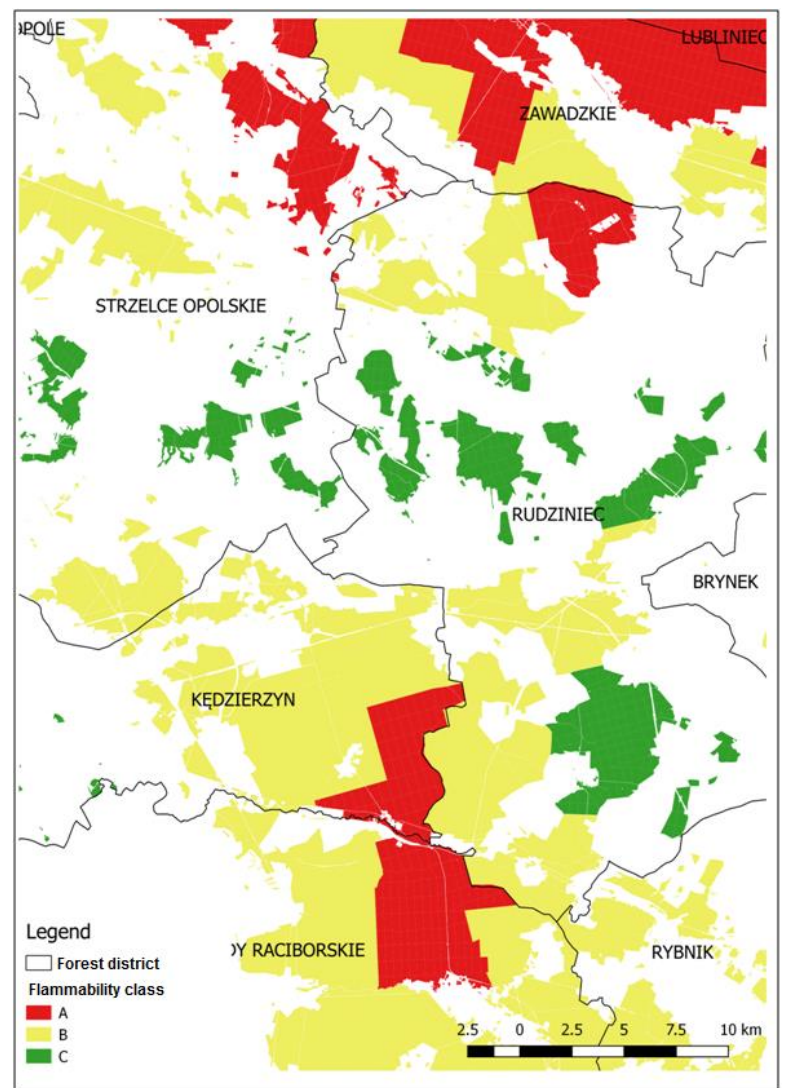

Figure 5 - Forest fire danger map for Regional Directorate in Katowice - flammability classes at the forest range level. 


\section{Summary}

The current forest fire risk classification method enables determination of the forest fire risk category in the macro scale; the smallest classified area is the forest district. There was no possibility of estimating forest fire risk in the micro scale. It would be the significant premise to organise a more efficient fire protection system, including creating the infrastructure and operational planning for rescue services. It would be the fulfilment of the INSPIRE directive, which requires classification and mapping of forest risk at that level. The elaborated method adopts forest habitat type as a base for classification. Forest habitat types determine the type of soil cover fuel, which is measure of forest fire susceptibility expressed by the number of forest fire and the burnt area. The sub-compartment is the classified unit and it is possible to generalise it, according to the elaborated rules, up to the level of compartment or forest range. The elaborated pattern, which includes flammability indices for the number of forest fires and the burnt area between 2007 - 2017, enables determination of the flammability class of forest stands as A - high class, B - medium class and C - low class, using forest habitat type and soil cover type. The method presented in this paper can be used in practice. The most detailed classification at the sub-compartment level might be useful for operational planning and organisation of the rescue action. The compartment level could be used for planning forest fire trails, water supply points and during suppression of large forest fires. The most generalised level, the level of forest range, can be useful during elaboration of procedures in the event of forest fire, lookout towers or equipment base localisation. 